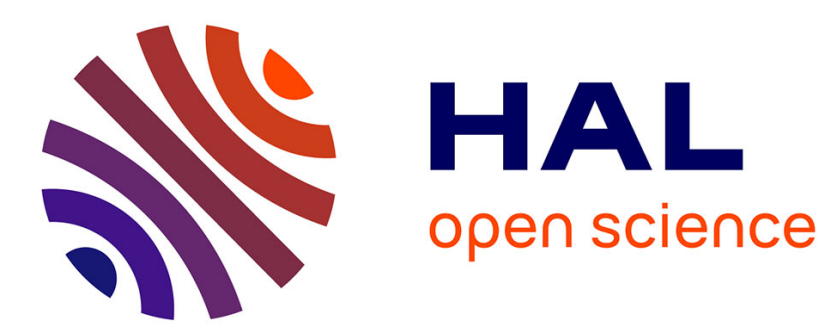

\title{
Has the employment status of people living with HIV changed since the early 2000s?
}

Margot Annequin, France Lert, Bruno Spire, Rosemary Dray-Spira, The Vespa2 Study Group

\section{- To cite this version:}

Margot Annequin, France Lert, Bruno Spire, Rosemary Dray-Spira, The Vespa2 Study Group. Has the employment status of people living with HIV changed since the early 2000s?. AIDS. Official journal of the international AIDS Society, 2015, 29 (12), pp.1537-1547. 10.1097/QAD.0000000000000722 . hal-01319107

\section{HAL Id: hal-01319107 https://hal.sorbonne-universite.fr/hal-01319107}

Submitted on 20 May 2016

HAL is a multi-disciplinary open access archive for the deposit and dissemination of scientific research documents, whether they are published or not. The documents may come from teaching and research institutions in France or abroad, or from public or private research centers.
L'archive ouverte pluridisciplinaire HAL, est destinée au dépôt et à la diffusion de documents scientifiques de niveau recherche, publiés ou non, émanant des établissements d'enseignement et de recherche français ou étrangers, des laboratoires publics ou privés. 
Has the employment status of people living with HIV changed since the early 2000s?

Running head: Changes in PLWHIV employment status

Margot ANNEQUIN ${ }^{1,2^{*}}$, France LERT ${ }^{3,4}$, Bruno SPIRE ${ }^{5,6,7}$, Rosemary DRAY-SPIRA ${ }^{1,2}$ and the VESPA2

Study Group*

${ }^{1}$ INSERM, UMR_S 1136, Pierre Louis Institute of Epidemiology and Public Health, Department of social epidemiology,75012, Paris, France,

${ }^{2}$ Sorbonne Universités, UPMC Univ Paris 06, UMR_S 1136 ,Pierre Louis Institute of Epidemiology and Public Health, Department of social epidemiology,75012, Paris, France,

${ }^{3}$ INSERM, U1018, Center for Research in Epidemiology and Population Health, Department of epidemiology of Occupational and Social Determinants of Health, Villejuif, France,

${ }^{4}$ Versailles Saint-Quentin-en-Yvelines University, Villejuif, France,

${ }^{5}$ INSERM, UMR912, Economics and Social Sciences Applied to Health \& Analysis of Medical Information (SESSTIM), Marseille, France,

${ }^{6}$ Aix Marseille University, UMR_S912, IRD, Marseille, France,

${ }^{7}$ ORS PACA, Southeastern Health Regional Observatory, Marseille, France

* See Appendix

\section{Correspondence and reprint requests}

Margot Annequin

INSERM U1136

Hopital Paul Brousse, 16 Av. Paul Vaillant-Couturier, 94807 Villejuif Cedex, France

Tel: +33 177747411 / Fax: +33 177747403

E-mail: margot.annequin@inserm.fr

\section{Conflicts of Interest and Sources of Funding}

The authors have no conflict of interest to disclose.

The VESPA-2003 and VESPA-2011 surveys were sponsored and funded by the ANRS (Agence Nationale de Recherches sur le SIDA et les Hépatites Virales). Margot Annequin is the recipient of a PhD grant from EHESP (Ecole des Hautes Etudes en Santé Publique) -School of Public Health, Rennes.

3611 words

4 Tables and 1 Figure

1 Supplementary Table 


\section{Abstract}

Objectives: In a context marked by major changes in the field of HIV and in the general socioeconomic context, this study aimed at investigating changes in the employment situation of people living with HIV (PLWHIV) in France since the early 2000s.

Design: Repeated cross-sectional survey among two nationally representative samples of PLWHIV followed at hospital in France in $2003(\mathrm{~N}=2,932)$ and $2011(\mathrm{~N}=3,022)$.

Methods: Differences between 2003 and 2011 in 1) rates of employment, unemployment and inactivity and 2) rates of work cessation and access to work following HIV diagnosis were measured using two-step multivariate Poisson regression models adjusted for individual sociodemographic determinants of position on the labor market, and then additionally for health status characteristics.

Results: Overall, among working-age PLWHIV 60.9\% in 2003 and 59.6\% in 2011 were employed; $12.6 \%$ and $15.8 \%$, respectively, were unemployed; and $26.5 \%$ and $24.6 \%$, respectively, were inactive. Adjusting for socio-demographic determinants of position on the labor market, while employment rate was not different in 2011 compared to 2003, inactivity rate significantly decreased (adjusted Prevalence Rate Ratio: 0.83, 95\% Confidence Interval: [0.72-0.96]) and unemployment rate significantly increased (1.28 [1.04-1.57]). After additional adjustment for health status characteristics, the difference was no longer significant for inactivity (0.89 [0.771.03]) but remained significant for unemployment (1.55 [1.24-1.93]). Compared to 2003, in 2011 transitions to unemployment following HIV diagnosis tended to be more frequent (1.58 [0.92$2.68])$ and access to work was significantly less frequent (0.57 [0.33-0.99]).

Conclusions: Improvements in HIV care have not translated into improvements in PLWHIV's situation regarding employment.

Keywords: Employment status; Disability; Socioeconomic factors; France; HIV infection 


\section{Introduction}

In the general population, work constitutes a central dimension of individuals living conditions by providing them with financial support, social status and identity [1]. In addition, employment status and, for those employed, working conditions and organization have major effects on health $[2,3]$. Among people living with HIV (PLWHIV) as well, employment status has been shown to be an independent predictor of adherence to treatment, morbidity and mortality [4-7].

Studies conducted in various Western countries in the early 2000 s provided evidence that early in the combined antiretroviral therapy (cART) era, HIV infection negatively affected individual chances of maintaining in and accessing/returning to employment [8-12]. This deleterious effect of HIV infection on employment was shown to occur from the very first months following disease onset [13] through various mechanisms including disease severity and HIVrelated discrimination [14]. As in the general population, socio-demographic characteristics including age, sex, education, country of citizenship and family status constitute major determinants of PLWHIV's position on the labor market $[11,15]$. HIV-infected women, migrants and drug users are particularly disadvantaged compared to men who have sex with men [11].

Major changes have occurred over the past decade, both in the field of HIV and in the broader general socioeconomic context, which may have resulted in changes in the burden of HIV infection on employment. First, the sustained use of cART has resulted in marked decreases in HIV-related morbidity and mortality $[16,17]$, but also in a rise in the frequency of various nonAIDS related conditions $[18,19]$ which substantially affect PLWHIV's chances of maintaining in employment [15]. Second, in addition to PLWHIV's ageing, the changing face of the HIV epidemics in Europe has resulted in increasing proportions of persons with a disadvantaged position on the labor market among PLWHIV - especially women and migrants originating from Sub-Saharan Africa $[20,21]$. Third, the economic crisis of 2008 has had severe and long-lasting effects on employment throughout Europe [22], and people affected by a chronic condition may be particularly affected [23-25]. 
In this changing context, the present study aimed at investigating changes in PLWHIV's situation regarding employment since the early 2000s in France. More specifically, our objectives were to measure changes over time in 1) PLWHIV's rates of employment, unemployment and inactivity and 2) early labor market transitions following HIV diagnosis, accounting for changes in individuals' socio-demographic determinants of position on the labor market and health status. We hypothesized that the potentially beneficial effects of recent HIV care improvements on PLWHIV's situation regarding employment may have been counterbalanced by concurrent changes in the characteristics of the HIV epidemics and the general socioeconomic context. 


\section{Methods}

\section{Study design}

The study was based on data of a repeated cross-sectional survey conducted among two large nationally representative samples of HIV-infected people followed at hospital in France in 2003 and 2011, with the primary aim of assessing the various dimensions of socioeconomic conditions and health of PLWHIV in France in their diversity and their changes over time. Both surveys were conducted among random samples of hospital outpatients aged 18 or older, diagnosed HIVinfected for at least 6 months, and either French-citizens or immigrants living in France for at least 6 months. The VESPA-2003 survey was conducted between December 2002 and September 2003 amongst 2,932 PLWHIV recruited in 102 hospital departments in mainland France. Its methodology has been extensively described elsewhere [26]. The VESPA-2011 survey was conducted between April 2011 and January 2012 amongst 3,022 PLWHIV recruited in 73 hospital departments in mainland France, using a similar design as detailed elsewhere [27]. In both surveys, participants answered a standardized questionnaire administered face-to-face by a trained interviewer including detailed questions on sociodemographic characteristics, living conditions, health and healthcare. To allow comparisons, a number of key questions were kept the same between surveys. Participants were additionally asked to complete a self-administered questionnaire including an assessment of health-related quality of life (HRQL) using generic scales from the Medical Outcomes Study (MOS): the 36-item Short-Form health survey instrument (SF36) [28] in VESPA-2003 and its 12-item subset (SF-12) [29] in VESPA-2011. Both scales have been shown to have discriminant validity and to provide appropriate measures of HRQL. Clinical and laboratory information were documented from medical records.

Data were weighted to account for sampling design and non-participation. Details about the weighting procedure are provided elsewhere [27]. Both surveys received approval from the French Advisory Committee on Information Processing in Material Research in the Field of Health 
(CCTIRS) and met the ethical requirements of the French National Commission for Computing and Liberties (CNIL).

\section{Variables of interest}

Employment status at the time of interview was documented for all participants, based on similar questions in both surveys. In line with the definition of the International Labour Organization, employment status was categorized in two steps as follows. First, participants were considered employed if they reported having a job (either paid or voluntary), regardless of professional status and working time (full time/part time), or if they were on sick leave for less than 6 months. Then, among participants who were not employed, individuals were categorized as either unemployed if they reported having actively sought work within the preceding 3 months or inactive otherwise, including students, retirees, people on disability (recipients of a disability benefit or on sick leave for more than 6 months) and those with family responsibilities. In addition, employment status at the time of HIV diagnosis (employed or not) was documented for respondents diagnosed HIV-infected within the 36 months preceding the survey.

We considered socio-demographic characteristics (age, sex, citizenship, educational level and household composition) and lifetime history of intravenous drug use as indicators of sociodemographic determinants of individuals' position on the labor market. Educational level was measured using maximum attained level of education in VESPA-2003 and highest diploma obtained in VESPA-2011, and dichotomized as low (primary or secondary education in VESPA2003; high school diploma or lower in VESPA-2011) or high (higher education in VESPA-2003; tertiary degree in VESPA-2011). Health status characteristics documented from medical records included indicators of HIV disease advancement (duration since HIV diagnosis at the time of the survey; immune status at the time of diagnosis; status regarding combination antiretroviral therapy (CART) and HIV viral load (VL) at the time of the survey) and information on history of Hepatitis C. For participants who completed the self-administered questionnaire, the physical 
component summary (PCS) for physical HRQL and the mental component summary (MCS) for mental HRQL were computed using the 12 items common to the SF-12 and the SF-36 scales. These scores range from 0 to 100 , with higher values denoting better HRQL. Impaired physical or mental HRQL was defined by a score below the first quartile of the distribution by age and sex in the French general population of, respectively, the PCS and the MCS [30].

\section{Statistical Analyses}

Analyses included participants of the VESPA-2003 and VESPA-2011 surveys of working-age (2564 years old) at the time of the survey and diagnosed HIV-infected in 1996 or later, i.e. in the era of cART availability. Individuals with missing information for variables with $<1 \%$ missing values were excluded.

Employment, unemployment and inactivity rates (each expressed as a percentage of the whole study population) were estimated in 2003 and in 2011, overall and according to individuals' sociodemographic determinants of position on the labor market and health status characteristics. Adjusted prevalence rate ratios (aPRR) comparing overall employment, unemployment and inactivity rates between 2003 and 2011 were assessed using three separate multivariate Poisson regression models with a robust variance estimator [31]. Each model considered the whole study population and compared the probability of being, respectively, employed (vs. unemployed or inactive), unemployed (vs. employed or inactive), or inactive (vs. employed or unemployed) in 2011 versus 2003. In a first step, models were adjusted for individual socio-demographic determinants of position on the labor market, thus providing estimates of the comparison of PLWHIV's employment status between 2003 and 2011 controlling for changes in individuals profile over time. Then, in order to estimate whether changes in PLWHIV's health contributed to differences in employment status between 2003 and 2011, additional adjustment for health status characteristics was performed. 
Labor market transitions following HIV diagnosis were assessed among the sub-sample of participants diagnosed HIV-infected within the 36 months preceding the survey in VESPA-2003 and VESPA-2011. Rates of work cessation (distinguishing between transitions from employment to i) unemployment and ii) inactivity) and access to work (transition from non-employment to employment) between HIV diagnosis and survey time were compared between 2003 and 2011, using multivariate Poisson regression models adjusted for individual socio-demographic determinants of position on the labor market and health status characteristics.

Individuals with unknown CD4 at time of diagnosis or unknown VL at time of the survey and those who did not complete the self-administered questionnaire were included in the analyses using missing categories for immune status at diagnosis, status regarding CART and VL at the time of the survey, and HRQL, respectively. Because these information may not be missing at random, we conducted sensitivity analyses assigning all participants with missing data for each of these three covariates to either the least favorable (ie, $<200 \mathrm{CD} 4 / \mathrm{mm}^{3}$ or AIDS; not on ART; impaired physical and mental HRQL, respectively) or the most favorable situation (ie, $\geq 500 \mathrm{CD} 4 / \mathrm{mm}^{3}$; on

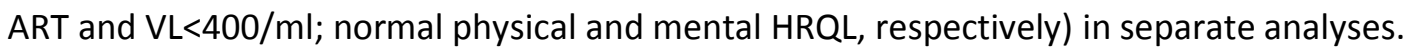

All analyses were performed using Stata $12^{\circledR}($ Stata Corporation, College Station, TX) and accounted for the complex sampling design and data weighting so that estimates are representative of the whole population of HIV-infected people followed at hospital in France. 


\section{Results}

\section{Characteristics of the study population}

Of a total of 2,676 participants (1,010 participants of VESPA-2003 and 1,666 participants of VESPA-2011) of working-age at the time of interview and diagnosed HIV-infected in 1996 or later, 16 individuals with missing information on educational level $(n=3)$ or Hepatitis C history $(n=13)$ were excluded. The 2,660 participants included were predominantly men (64.8\%); $28.0 \%$ were citizens of a country of sub-Saharan Africa and more than a third (36.2\%) were men who have sex with men. As shown in Table 1, socio-demographic and health characteristics of PLWHIV differed between 2003 and 2011. As compared to 2003, in 2011 PLWHIV were older (median age: 43 versus 39 years, $\mathrm{p}<0.001)$ and more frequently women $(37.2 \%$ versus $32.1 \%, \mathrm{p}=0.05)$ and citizens of a country of sub-Saharan Africa (31.0\% versus 22.9\%, $\mathrm{p}<0.001)$. In addition, in 2011 PLWHIV had been diagnosed HIV-positive for a longer time than in 2003 (median time since HIV diagnosis: 7.4 versus 3.8 years, $\mathrm{p}<0.001$ ), their CD4 cell count at diagnosis was higher (median: 358 versus $303, p<0.001)$ and they were more frequently in virological success $(83.2 \%$ versus $62.3 \%$, $p<0.001)$

Employment status at the time of the survey

Overall, approximately six PLWHIV out of ten were employed in both surveys $(60.9 \%$ in VESPA2003 and $59.6 \%$ in VESPA-2011, $p=0.56$ ). Among them, $6.2 \%$ and $4.7 \%$, respectively, were on sick leave at the time of interview. The rate of unemployment increased by 3.2 points, from $12.6 \%$ in 2003 to $15.8 \%$ in 2011 (relative change: $+25.2 \%, p=0.04$ ) and the rate of inactivity decreased by 1.9 points, from $26.5 \%$ to $24.6 \%$, respectively (relative change: $-7.2 \%, p=0.34$ ). Main reasons for inactivity were disability (almost half of the inactive in 2003 and $2011-47.0 \%$ and $48.4 \%$, respectively, $\mathrm{p}=0.76)$ and retirement $(10.2 \%$ and $25.6 \%$, respectively, $\mathrm{p}=0.001)$. 
As shown in Table 2, in 2003 and 2011 employment status markedly differed according to socio-demographic characteristics. Employment rates were the highest among men $167.0 \%$ in VESPA-2003 and 64.7\% in VESPA-2011), French-nationals (67.6\% and 63.9\%, respectively), individuals aged $40-49$ years ( $65.3 \%$ and $64.5 \%$, respectively), those highly educated $(72.5 \%$ and $71.6 \%$, respectively) and those living in cohabiting partnership without children $(71.6 \%$ and $66.1 \%$, respectively). Unemployment was particularly high among women (16.4\% and $21.0 \%$, respectively in 2003 and 2011), individuals aged less than 40 years ( $14.9 \%$ and $22.5 \%$, respectively) and those originating from sub-Saharan Africa ( $22.8 \%$ and $26.5 \%$, respectively). Inactivity was particularly frequent among women ( $35.7 \%$ and $28.0 \%$, respectively), non-African immigrants ( $42.2 \%$ and $35.1 \%$, respectively), individuals aged 50 years or more ( $42.3 \%$ and $40.2 \%$, respectively) and those low-educated (31.9\% and $28.5 \%$, respectively). History of intravenous drug use was also associated with high rates of inactivity ( $53.4 \%$ and $50.0 \%$, respectively). Employment status additionally differed according to health status characteristics, with higher employment rates among individuals with the most favorable indicators regarding HIV disease advancement, comorbidity and health-related quality of life.

Adjusting for socio-demographic determinants of position on the labor market, the employment rate of PLWHIV was not different in 2011 as compared to 2003 (aPRR: 1.03, 95\% Confidence Interval: 0.96 to 1.10 ). Though, the rate of inactivity significantly decreased between 2003 and 2011 (aPRR: $0.83,95 \% \mathrm{Cl}: 0.72$ to 0.96 ), and the rate of unemployment significantly increased (aPRR 1.28, 95\% Cl: 1.04 to 1.57) (Tables 3 and 4).

After additional adjustment for health status characteristics, the difference in inactivity rate between 2003 and 2011 was no longer significant (aPRR: $0.89,95 \% \mathrm{Cl}: 0.77$ to 1.03 ). In contrast, the unemployment rate remained significantly higher in 2011 compared to 2003 (aPRR: 1.55, 95\%Cl: 1.24 to 1.93$)$. These results remained consistent in sensitivity analyses. 
A total of 427 participants in VESPA-2003 and 366 participants in VESPA-2011 had been diagnosed HIV-infected within the 36 months preceding the interview. These recently diagnosed individuals did not differ between 2003 and 2011 regarding socio-demographic determinants of position on the labor market (supplementary Table S1); though, compared to 2003 those included in 2011 were less likely to have reached an advanced stage of HIV disease at the time it was diagnosed $(29.1 \%$ versus $37.6 \%, p=0.06)$ and to have a history of Hepatitis C $(3.0 \%$ versus $6.0 \%$, $p=0.06)$, and more likely to be in virological success $(69.7 \%$ versus $57.1 \%, p=0.007)$.

Among recently diagnosed participants employed at the time of HIV diagnosis, $10.1 \%$ in VESPA-2003 and $19.2 \%$ in VESPA-2011 had turned unemployed by the time of interview $(p=0.01)$; and $14.8 \%$ and $15.4 \%$, respectively, had become inactive $(p=0.88)$ (Figure 1 ). Adjusting for individuals' socio-demographic determinants of position on the labor market and health status characteristics, the rate of transition from employment to unemployment between times of HIV diagnosis and interview tended to be higher among participants of VESPA-2011 compared to participants of VESPA-2003 (aPRR: 1.58, 95\%Cl: 0.92 to 2.68). The rate of transition from employment to inactivity did not differ between participants of both surveys (aPRR: $1.05,95 \% \mathrm{Cl}$ : 0.63 to 1.76$)$.

Among recently diagnosed participants not employed at the time of HIV diagnosis, the proportion who had accessed employment by the time of interview was $29.0 \%$ in VESPA-2003 and $21.2 \%$ in VESPA-2011 (Figure 1). Adjusting for individuals' socio-demographic determinants of position on the labor market and health status characteristics, the rate of access to work between times of HIV diagnosis and interview was significantly lower among participants of VESPA-2011 compared to participants of VESPA-2003 (aPRR: $0.54,95 \% \mathrm{Cl}: 0.32$ to 0.90 ).

These results remained consistent in sensitivity analyses. 


\section{Discussion}

Our results indicate that in France, the employment rate of PLWHIV has remained consistently low over the past decade. Though, this apparent stability masks diverging trends over time in the labor market position of PLWHIV who are out of employment. Indeed, we found that between 2003 and 2011, while economic inactivity decreased, unemployment increased. This suggests that despite the major improvements in HIV care and treatments occurred over the past decade, the employment of PLWHIV, a population which is mainly made of working age people, still remains problematic in the current context and therefore deserves a special attention.

The VESPA-2003 and VESPA-2011 studies, because they were conducted at two different time points using similar study design and questions, provide unique datasets to investigate changes in PLWHIV health and living conditions over a period marked by major changes both in the field of HIV and more broadly in terms of socioeconomic, political and social context. The nationalrepresentative nature of the two datasets constitutes a major strength of our study, as well as the availability of detailed individual information allowing distinguishing between unemployment and economic inactivity and accounting for changes over time in PLWHIV's sociodemographic and health profiles. However, it should be acknowledged that the study is restricted to HIV-infected people attending hospital for HIV care. Nevertheless, HIV care is essentially provided at hospital in France and since 2006 the experts have recommended that all PLWHIV have at least an annual checkup at hospital [32], suggesting that our estimates are likely to apply to the vast majority of PLWHIV in care in France. In addition, the causal interpretation of our findings on changes over time should remain cautious, especially because analyses consisted of comparisons between two cross-sectional surveys rather than on individual longitudinal data. Furthermore, the changes we report among PLWHIV may partly reflect changes occurred more generally in the French general population. Investigating the proper role of HIV infection on these changes would have required a control group of HIV-negative individuals. 
The employment rates of approximately 60\% we report among PLWHIV in 2003 and 2011 are much lower than the corresponding rates in the French general population aged 20-64 years (69.7\% in 2003 and 69.3\% in 2011) [33]. This is consistent with previous studies which reported a lower employment rate among PLWHIV compared to the general population in France [15] as well as in other European countries including Denmark [34], Belgium [35], Spain [36] or UK [37]. In contrast, our findings provide evidence of high rates of both economic inactivity and unemployment among PLWHIV. The inactivity rates we report are substantially higher among PLWHIV aged 25-49 years compared to the French general population of similar age range ( $23 \%$ in 2003 and $18 \%$ in 2011 versus $12 \%$ and $11 \%$, respectively, in the general population [38]), while among people aged 50-64 years figures appear less contrasted, reaching more than forty percent of individuals in this age category both among PLWHIV and in the general population $(42 \%$ and $40 \%$ versus $43 \%$ and $41 \%$ [38], respectively). Even in the era of highly potent antiretroviral treatments, inactivity appears to be primarily driven by disability among PLWHIV, probably as a consequence of HIV disease itself but also comorbidities. Similarly, disability retirement was reported to be increased among PLWHIV compared to the general population in Denmark [34]. By providing evidence of high rates of unemployment among PLWHIV $(12.6 \%$ in 2003 and $15.8 \%$ in 2011, compared to $5.7 \%$ and $6.1 \%$, respectively, in the general population [38]), our results additionally suggest that the low employment rate of PLWHIV results not only from their exclusion from the labor market but also from a decreased employability of those who remain in the labor force.

We found that controlling for individual socio-demographic determinants of position on the labor market, the inactivity rate of PLWHIV, although persistently high, significantly decreased between 2003 and 2011. This decrease was no longer significant after accounting for health status characteristics, suggesting that it likely results from improvements in HIV care occurred over the study period. Such a finding, by providing evidence for PLWHIV's increased ability to work, is consistent with previous findings supporting the 'normalization' of PLWHIV's life in the era of 
CART [39]. This decrease may also reflect changes in eligibility requirements for disability introduced in France in 2005 [40], which may have resulted in reduced access to disability benefits for PLWHIV. Yet, among participants of the VESPA studies the proportion of recipients of a disability benefit did not decrease between 2003 (15.7\%) and 2011 (18.1\%), suggesting that such changes are unlikely to explain the decrease in inactivity we report.

In contrast with inactivity figures, unemployment significantly increased between 2003 and 2011. Previous reports showed that adverse employment outcomes arise very early in the course of HIV disease $[9,10,13,15,34]$. Our results on early labor market transitions (i.e., within the first 36 months) following HIV diagnosis confirm the high frequency of such early changes; and furthermore suggest that the increase in unemployment we report is likely to result from lower chances of both maintaining in employment and accessing (or returning) to work in 2011 compared to 2003. This may be related to various underlying mechanisms. First, the increase we report in terms of adverse labor market transitions may result from the overall deterioration of the economic situation generally affecting the French labor market since 2008 [38]. Second, this may reflect the increasing burden of comorbidities, including e.g. cardiovascular disease or depression, which have been shown to impair PLWHIV's employment status [15]. Indeed, in our study although analyses were adjusted for health status as measured by HIV disease advancement, hepatitis C coinfection and health-related quality of life, differences in comorbidities over time could not be accounted for since the information was not available in the 2003 survey. Third, experiences of discrimination related either to HIV status or other characteristics of the individuals, which constitute independent predictors of employment loss among PLWHIV [14], were very frequent in France in 2011. Indeed, 24\% of the VESPA-2011 respondents having applied for a job reported having been discriminated against when seeking a job in the past two years, and $6 \%$ of the participants reported experiences of discrimination in their work environment (if any) [41]. Though, because comparable figures were not available in the VESPA-2003 study, we were not able to measure their contribution to the reported trends. 
In conclusion, our study suggests that improvements in HIV care occurred since the early 2000 s have not translated into improvements in PLWHIV's situation regarding employment. Although PLWHIV have seen their ability to work increased in the recent years, these improvements appear to have been offset by increasing barriers to maintain in and/or access to employment. The respective roles of socioeconomic recession, comorbidities and discrimination deserve to be further investigated to help address the issue of employment of PLWHIV in the current context. 


\section{Acknowledgements and funding}

The authors are deeply grateful to people living with HIV who agreed to participate in the ANRSVespa2 study and to all investigators in participating hospitals.

They also thank Yann Le Strat (InVS, Saint-Maurice), Lise Cuzin (Hopital Purpan, Toulouse) and Laurence Meyer (INSERM UMR-S 1018,Le Kremlin Bicêtre) for their methodological support; and the community-based organizations AIDES and Act-Up Paris for their ground support in the implementation of the ANRS-Vespa2 study.

The VESPA-2003 and VESPA-2011 surveys were sponsored and funded by the ANRS (Agence Nationale de Recherches sur le SIDA et les Hépatites Virales).

Margot Annequin is the recipient of a PhD grant from EHESP (Ecole des Hautes Etudes en Santé Publique) -School of Public Health, Rennes.

\section{Competing interests}

The authors have no competing interest to declare.

\section{Author Contributions}

MA, FL and RDS contributed to the study design, data interpretation and manuscript preparation. MA conducted statistical analyses. MA and RDS drafted the manuscript. FL and BS critically revised the manuscript. 


\section{References}

1. Berkman LF. Commentary: The hidden and not so hidden benefits of work: identity, income and interaction. Int J Epidemiol 2014,43:1517-1519.

2. Bartley M, Sacker A, Clarke P. Employment status, employment conditions, and limiting illness: prospective evidence from the British household panel survey 1991-2001. J Epidemiol Community Health 2004,58:501-506.

3. Roelfs DJ, Shor E, Davidson KW, Schwartz JE. Losing life and livelihood: a systematic review and meta-analysis of unemployment and all-cause mortality. Soc Sci Med 2011,72:840-854.

4. International Labour Office, (ILO). The impact of employment on HIV treatment adherence. In. Edited by International Labour Organization. Geneva: 2013. URL: http://www.ilo.org/aids/Publications/WCMS 230625/lang--en/index.htm.

5. Richardson LA, Milloy MJ, Kerr TH, Parashar S, Montaner JS, Wood E. Employment predicts decreased mortality among HIV-seropositive illicit drug users in a setting of universal HIV care. J Epidemiol Community Health 2014,68:93-96.

6. Dray-Spira R, Gueguen A, Persoz A, Deveau C, Lert F, Delfraissy JF, et al. Temporary employment, absence of stable partnership, and risk of hospitalization or death during the course of HIV infection. J Acquir Immune Defic Syndr 2005,40:190-197.

7. Delpierre C, Cuzin L, Lauwers-Cances V, Datta GD, Berkman L, Lang T. Unemployment as a risk factor for AIDS and death for HIV-infected patients in the era of highly active antiretroviral therapy. Sex Transm Infect 2008,84:183-186.

8. Dray-Spira R, Lert F, Marimoutou C, Bouhnik AD, Obadia Y. Socio-economic conditions, health status and employment among persons living with HIV/AIDS in France in 2001. AIDS Care 2003,15:739-748.

9. Goldman DP, Bao Y. Effective HIV treatment and the employment of HIV(+) adults. Health Serv Res 2004,39:1691-1712.

10. Rabkin JG, McElhiney M, Ferrando SJ, Van Gorp W, Lin SH. Predictors of employment of men with HIV/AIDS: a longitudinal study. Psychosom Med 2004,66:72-78.

11. Dray-Spira R, Lert F, Group VS. Living and working with HIV in France in 2003: results from the ANRS-EN12-VESPA Study. AIDS 2007,21(Suppl 1):S29-36.

12. Dray-Spira R, Gueguen A, Ravaud JF, Lert F. Socioeconomic differences in the impact of HIV infection on workforce participation in France in the era of highly active antiretroviral therapy. Am J Public Health 2007,97:552-558.

13. Dray-Spira R, Persoz A, Boufassa F, Gueguen A, Lert F, Allegre T, et al. Employment loss following HIV infection in the era of highly active antiretroviral therapies. Eur J Public Health 2006,16:89-95.

14. Dray-Spira R, Gueguen A, Lert F, Group VS. Disease severity, self-reported experience of workplace discrimination and employment loss during the course of chronic HIV disease: differences according to gender and education. Occup Environ Med 2008,65:112-119.

15. Dray-Spira R, Legeai C, Le Den M, Boue F, Lascoux-Combe C, Simon A, et al. Burden of HIV disease and comorbidities on the chances of maintaining employment in the era of sustained combined antiretroviral therapies use. AIDS 2012,26:207-215.

16. Smith CJ, Ryom L, Weber R, Morlat P, Pradier C, Reiss P, et al. Trends in underlying causes of death in people with HIV from 1999 to 2011 (D:A:D): a multicohort collaboration. Lancet 2014,384:241-248.

17. Morlat $P$, Roussillon $C$, Henard S, Salmon D, Bonnet F, Cacoub P, et al. Causes of death among HIV-infected patients in France in 2010 (national survey): trends since 2000. AIDS 2014,28:1181-1191.

18. Mocroft A, Reiss P, Gasiorowski J, Ledergerber B, Kowalska J, Chiesi A, et al. Serious fatal and nonfatal non-AIDS-defining illnesses in Europe. J Acquir Immune Defic Syndr 2010,55:262270 . 
19. Hasse B, Ledergerber B, Furrer H, Battegay M, Hirschel B, Cavassini M, et al. Morbidity and aging in HIV-infected persons: the Swiss HIV cohort study. Clin Infect Dis 2011,53:1130-1139.

20. Del Amo J, Likatavicius G, Perez-Cachafeiro S, Hernando V, Gonzalez C, Jarrin I, et al. The epidemiology of HIV and AIDS reports in migrants in the 27 European Union countries, Norway and Iceland: 1999-2006. Eur J Public Health 2011,21:620-626.

21. Hamers FF, Downs AM. The changing face of the HIV epidemic in western Europe: what are the implications for public health policies? The Lancet 2004,364:83-94.

22. European Commission. EU Employment and Social Situation. In: Quaterly Review. Edited by European Union. Luxembourg: 2014. URL: http://ec.europa.eu/social/BlobServlet?docld=11565\&langld=en.

23. Reeves A, Karanikolos M, Mackenbach J, McKee M, Stuckler D. Do employment protection policies reduce the relative disadvantage in the labour market experienced by unhealthy people? A natural experiment created by the Great Recession in Europe. Social Science \& Medicine 2014,121:98-108.

24. Minton JW, Pickett KE, Dorling D. Health, employment, and economic change, 1973-2009: repeated cross sectional study. BMJ 2012,344:e2316.

25. Holland P, Burstrom B, Whitehead M, Diderichsen F, Dahl E, Barr B, et al. How do macro-level contexts and policies affect the employment chances of chronically ill and disabled people? Part I: The impact of recession and deindustrialization. Int J Health Serv 2011,41:395-413.

26. Peretti-Watel P, Riandey B, Dray-Spira R, Bouhnik A, Sitta R, Obadia Y, et al. Surveying the HIV-Positive Population inf France. The ANRS-EN12-VESPA 2003 Survey. Population 2005,60:525-550.

27. Tron L, Lert F, Spire B, Dray-Spira R, group AN-Vs. Tobacco Smoking in HIV-Infected versus General Population in France: Heterogeneity across the Various Groups of People Living with HIV. PLoS One 2014,9:e107451.

28. Leplege A, Ecosse E, Verdier A, Perneger TV. The French SF-36 Health Survey: translation, cultural adaptation and preliminary psychometric evaluation. J Clin Epidemiol 1998,51:10131023.

29. Ware JEJ, Kosinski M, Keller SD. A 12-Item Short-Form Health Survey: Construction of Scales and Preliminary Tests of Reliability and Validity. Medical Care 1996,34:220-233.

30. Preau M, Marcellin F, Carrieri MP, Lert F, Obadia Y, Spire B. Health-related quality of life in French people living with HIV in 2003: results from the national ANRS-EN12-VESPA Study. AIDS 2007,21 (Suppl 1):S19-27.

31. Barros A, Hirakata V. Alternatives for logistic regression in cross-sectional studies: an empirical comparison of models that directly estimate the prevalence ratio. BMC Medical Research Methodology 2003,3:21.

32. Morlat P. [Medical care of people living with HIV. Guidelines of the experts group. 2013 Report] In French. Paris: La documentation française; 2013.

33. EuroStat. Statistical Office of the European Union. In: http://ec.europa.eu/eurostat/web/labour-market/statistics-illustrated.

34. Legarth R, Omland LH, Kronborg G, Larsen CS, Pedersen C, Pedersen G, et al. Employment status in persons with and without HIV infection in Denmark: 1996-2011. AIDS 2014,28:14891498.

35. Pezeril C. [First results of the survey on life condition of people living with HIV in Brussels and Wallonia] In French. Bruxelles: Observatoire du sida et des sexualités; 2012. pp. 28.

36. Oliva J. Labour participation of people living with HIV/AIDS in Spain. Health Econ 2010,19:491-500.

37. Rodger AJ, Brecker N, Bhagani S, Fernandez T, Johnson M, Tookman A, et al. Attitudes and barriers to employment in HIV-positive patients. Occup Med (Lond) 2010,60:423-429.

38. INSEE. National Institute of Statistics and Economic Studies. In: http://www.insee.fr/en/.

39. Pierret J. An analysis over time (1990-2000) of the experiences of living with HIV. Social Science \& Medicine 2007,65:1595-1605. 
40. Ravaud JF. [Definition, classification and epidemiology of disability] In French. Rev Prat 2009,59:1067-1074.

41. Marsicano E, Dray-Spira R, Lert F, Aubriere C, Spire B, Hamelin C, et al. Multiple discriminations experienced by people living with HIV in France: results from the ANRSVespa2 study. AIDS Care 2014,26(Suppl 1):S97-106. 
Table 1. Participants' socio-demographic determinants of position on the labor market and health status characteristics, VESPA-2003 and VESPA-2011 surveys

\begin{tabular}{|c|c|c|c|}
\hline & $\begin{array}{c}\text { VESPA-2003 }^{a} \\
(\mathrm{~N}=1,010)\end{array}$ & $\begin{array}{c}\text { VESPA-2011 }^{\mathrm{a}} \\
(\mathrm{N}=1,650)\end{array}$ & $P$-value ${ }^{b}$ \\
\hline \multicolumn{4}{|c|}{ Socio-demographic determinants of position on the labor market } \\
\hline \multicolumn{4}{|c|}{ Sex } \\
\hline Men & 67.9 & 62.8 & \multirow[t]{2}{*}{0.046} \\
\hline Women & 32.1 & 37.2 & \\
\hline \multicolumn{4}{|l|}{ Age (years) } \\
\hline 25-39 & 52.4 & 35.1 & \multirow[t]{3}{*}{$<0.001$} \\
\hline $40-49$ & 29.5 & 35.9 & \\
\hline $50-64$ & 18.1 & 29.0 & \\
\hline \multicolumn{4}{|l|}{ Country of citizenship } \\
\hline France & 67.2 & 62.4 & \multirow[t]{3}{*}{$<0.001$} \\
\hline Sub-Saharan Africa & 22.9 & 31.0 & \\
\hline Other & 9.9 & 6.6 & \\
\hline \multicolumn{4}{|l|}{ Educational level } \\
\hline High & 31.1 & 29.1 & \multirow[t]{2}{*}{0.33} \\
\hline Low & 68.9 & 70.9 & \\
\hline \multicolumn{4}{|l|}{ Household composition } \\
\hline Single, no children & 37.7 & 37.1 & \multirow[t]{5}{*}{0.52} \\
\hline Single with children & 9.6 & 11.8 & \\
\hline Cohabiting partner, no children & 23.9 & 23.2 & \\
\hline Cohabiting partner and children & 16.3 & 17.0 & \\
\hline Other cohabiting adults & 12.5 & 10.9 & \\
\hline \multicolumn{4}{|l|}{ History of intravenous drug use } \\
\hline No & 94.2 & 94.1 & \multirow[t]{2}{*}{0.91} \\
\hline Yes & 5.8 & 5.9 & \\
\hline \multicolumn{4}{|l|}{ Health status } \\
\hline Duration since HIV diagnosis & & & \\
\hline Less than 3 years & 39.1 & 17.9 & \multirow[t]{2}{*}{$<0.001$} \\
\hline 3 years or more & 60.9 & 82.1 & \\
\hline \multicolumn{4}{|l|}{ Immune status at HIV diagnosis } \\
\hline$<200 \mathrm{CD} 4 / \mathrm{mm}^{3}$ or AIDS & 33.1 & 28.5 & \multirow[t]{5}{*}{0.007} \\
\hline $200-349 \mathrm{CD} 4 / \mathrm{mm}^{3}$ & 19.4 & 16.6 & \\
\hline $350-499 \mathrm{CD} 4 / \mathrm{mm}^{3}$ & 13.5 & 18.1 & \\
\hline$\geq 500 \mathrm{CD} 4 / \mathrm{mm}^{3}$ & 23.1 & 22.9 & \\
\hline Missing & 10.9 & 13.9 & \\
\hline \multicolumn{4}{|l|}{ ART status and HIV viral load (VL) } \\
\hline On ART, VL $<400$ copies/ml & 62.3 & 83.2 & \multirow[t]{4}{*}{$<0.001$} \\
\hline On ART, VL $\geq 400$ copies $/ \mathrm{ml}$ & 12.1 & 4.2 & \\
\hline Not on ART & 23.0 & 10.3 & \\
\hline Missing & 2.6 & 2.3 & \\
\hline \multicolumn{4}{|l|}{ History of Hepatitis C } \\
\hline No & 90.3 & 92.1 & \multirow[t]{2}{*}{0.15} \\
\hline Yes & 9.7 & 7.9 & \\
\hline \multicolumn{4}{|l|}{ Health-Related Quality of Life (HRQL) } \\
\hline Normal & 22.1 & 21.4 & \multirow[t]{5}{*}{$<0.001$} \\
\hline Impaired mental HRQL & 12.0 & 8.4 & \\
\hline Impaired physical HRQL & 15.6 & 22.5 & \\
\hline Impaired physical and mental HRQL & 16.3 & 20.0 & \\
\hline Missing & 34.0 & 27.7 & \\
\hline
\end{tabular}

${ }^{a}$ Weighted percentages $\quad{ }^{b}$ Chi-square test 


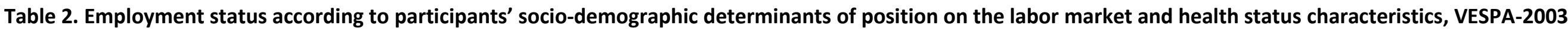
and VESPA-2011 surveys

\begin{tabular}{|c|c|c|c|c|c|c|c|c|}
\hline & \multicolumn{4}{|c|}{ VESPA-2003 } & \multicolumn{4}{|c|}{ VESPA-2011 } \\
\hline & $\begin{array}{c}\%^{\mathrm{a}} \\
\text { Employed }\end{array}$ & $\begin{array}{c}\%^{\mathrm{a}} \\
\text { Unemployed }\end{array}$ & $\begin{array}{c}\%^{\mathrm{a}} \\
\text { Inactive }\end{array}$ & $\begin{array}{c}P- \\
\text { value }^{b}\end{array}$ & $\begin{array}{c}\%^{\mathrm{a}} \\
\text { Employed }\end{array}$ & $\begin{array}{c}\%^{\mathrm{a}} \\
\text { Unemployed }\end{array}$ & $\begin{array}{c}\%^{\mathrm{a}} \\
\text { Inactive }\end{array}$ & $\begin{array}{c}P- \\
\text { value }^{b}\end{array}$ \\
\hline \multicolumn{9}{|c|}{ Socio-demographic determinants of position on the labor market } \\
\hline \multicolumn{9}{|c|}{ Sex } \\
\hline Men & 67.0 & 10.8 & 22.2 & $<0.001$ & 64.7 & 12.6 & 22.6 & $<0.001$ \\
\hline Women & 47.9 & 16.4 & 35.7 & & 51.0 & 21.0 & 28.0 & \\
\hline \multicolumn{9}{|l|}{ Age (years) } \\
\hline 25-39 & 61.4 & 14.9 & 23.7 & $<0.001$ & 61.3 & 22.5 & 16.2 & $<0.001$ \\
\hline $40-49$ & 65.3 & 12.4 & 22.2 & & 64.5 & 15.3 & 20.2 & \\
\hline $50-64$ & 51.7 & 5.9 & 42.3 & & 51.6 & 8.3 & 40.2 & \\
\hline \multicolumn{9}{|l|}{ Country of citizenship } \\
\hline France & 67.6 & 9.2 & 23.1 & $<0.001$ & 63.9 & 10.0 & 26.1 & $<0.001$ \\
\hline Sub-Saharan Africa & 47.6 & 22.8 & 29.6 & & 54.2 & 26.5 & 19.4 & \\
\hline Other & 45.7 & 12.1 & 42.2 & & 44.0 & 20.8 & 35.1 & \\
\hline \multicolumn{9}{|l|}{ Educational level } \\
\hline High & 72.5 & 12.7 & 14.7 & $<0.001$ & 71.6 & 13.0 & 15.4 & $<0.001$ \\
\hline Low & 55.5 & 12.6 & 31.9 & & 54.6 & 16.9 & 28.5 & \\
\hline \multicolumn{9}{|l|}{ Household composition } \\
\hline Single, no children & 64.2 & 9.7 & 26.1 & $<0.001$ & 59.4 & 13.9 & 26.8 & $<0.001$ \\
\hline Single with children & 42.4 & 15.6 & 42.0 & & 45.6 & 31.7 & 22.7 & \\
\hline Cohabiting partner, no children & 71.6 & 9.1 & 19.3 & & 66.1 & 8.2 & 25.7 & \\
\hline Cohabiting partner and children & 59.4 & 16.1 & 24.5 & & 63.8 & 15.9 & 20.2 & \\
\hline Other cohabiting adults & 46.1 & 21.6 & 32.3 & & 55.3 & 20.7 & 24.0 & \\
\hline \multicolumn{9}{|l|}{ History of intravenous drug use } \\
\hline No & 62.7 & 12.5 & 24.8 & $<0.001$ & 61.2 & 15.7 & 23.1 & 0.02 \\
\hline Yes & 32.3 & 14.3 & 53.4 & & 33.7 & 16.3 & 50.0 & \\
\hline \multicolumn{9}{|l|}{ Health status } \\
\hline \multicolumn{9}{|l|}{$\overline{\text { Duration since HIV diagnosis }}$} \\
\hline Less than 3 years & 56.0 & 16.4 & 27.5 & 0.01 & 56.3 & 24.8 & 18.9 & $<0.001$ \\
\hline 3 years or more & 64.0 & 10.2 & 25.8 & & 60.3 & 13.8 & 25.8 & \\
\hline \multicolumn{9}{|l|}{ Immune status at HIV diagnosis } \\
\hline$<200 \mathrm{CD} 4 / \mathrm{mm}^{3}$ or AIDS & 57.1 & 10.0 & 32.9 & 0.004 & 50.6 & 17.1 & 32.3 & $<0.001$ \\
\hline $200-349 \mathrm{CD} 4 / \mathrm{mm}^{3}$ & 58.6 & 15.5 & 25.8 & & 61.0 & 17.4 & 21.5 & \\
\hline $350-499 \mathrm{CD} 4 / \mathrm{mm}^{3}$ & 64.8 & 10.8 & 24.4 & & 70.0 & 11.0 & 18.9 & \\
\hline
\end{tabular}


$\geq 500 \mathrm{CD} 4 / \mathrm{mm}^{3}$

ART status and HIV viral load (VL)

On ART, VL $<400$ copies $/ \mathrm{ml}$

On ART, VL $\geq 400$ copies/m

Not on ART

History of Hepatitis C

No

Yes

Health-Related Quality of Life (HRQL)

Normal

Impaired mental HRQL

Impaired physical HRQ

Impaired physical and mental HRQL

69.9

12.9

64.0

48.6

59.5

62.9

42.4

78.3

73.9

63.0

43.9

${ }^{\mathrm{a}}$ Weighted percentages ${ }^{\mathrm{b}}$ Chi-square test
17.1

11.0

12.7
11.9

45.7

11.5

63.0

15.4

21.6

0.03

60.8

48.8

14.1

29.2

25.0

22.1

19.5

61.0

42.2

15.2

22.3

23.7

35.5

72.1

11.7

16.2

18.0

65.3

16.8

12.8

18.0

$\begin{array}{lll}10.0 & 27.0 & 63.3 \\ 15.3 & 40.9 & 52.9\end{array}$

29.1
0.01

0.002

0.002 
Table 3. Prevalence rate ratio of inactivity in 2011 versus 2003, adjusted for individual socio-demographic determinants of position on the labor market (Model 1) and additionally for health status characteristics (Model 2)

\begin{tabular}{|c|c|c|c|c|}
\hline & \multicolumn{2}{|c|}{ Model 1} & \multicolumn{2}{|c|}{ Model 2} \\
\hline & aPRR & {$[95 \% \mathrm{Cl}]$} & aPRR & {$[95 \% \mathrm{Cl}]$} \\
\hline \multicolumn{5}{|l|}{ Survey year } \\
\hline 2003 & 1 & & 1 & \\
\hline 2011 & $0.83^{*}$ & {$[0.72 ; 0.96]$} & 0.89 & {$[0.77 ; 1.03]$} \\
\hline \multicolumn{5}{|c|}{ Socio-demographic determinants of position on the labor market } \\
\hline \multicolumn{5}{|c|}{ Sex } \\
\hline Men & 1 & & 1 & \\
\hline Women & $1.53^{*}$ & {$[1.30 ; 1.80]$} & $1.54 *$ & {$[1.32 ; 1.80]$} \\
\hline \multicolumn{5}{|l|}{ Age (years) } \\
\hline 25-39 & 0.92 & {$[0.77 ; 1.11]$} & 0.97 & {$[0.80 ; 1.17]$} \\
\hline $40-49$ & 1 & & 1 & \\
\hline $50-64$ & $2.13^{*}$ & {$[1.79 ; 2.54]$} & $2.21 *$ & {$[1.87 ; 2.63]$} \\
\hline \multicolumn{5}{|l|}{ Country of citizenship } \\
\hline France & 1 & & 1 & \\
\hline Sub-Saharan Africa & 0.89 & {$[0.74 ; 1.08]$} & $0.74 *$ & {$[0.61 ; 0.89]$} \\
\hline Other & $1.35^{*}$ & {$[1.09 ; 1.67]$} & 1.18 & {$[0.95 ; 1.46]$} \\
\hline \multicolumn{5}{|l|}{ Educational level } \\
\hline High & 1 & & 1 & \\
\hline Low & $1.74^{*}$ & {$[1.41 ; 2.14]$} & $1.66 *$ & {$[1.35 ; 2.04]$} \\
\hline \multicolumn{5}{|l|}{ Household composition } \\
\hline Single, no children & 1.15 & {$[0.96 ; 1.37]$} & 1.14 & {$[0.95 ; 1.36]$} \\
\hline Single with children & 1.07 & {$[0.82 ; 1.39]$} & 1.01 & {$[0.78 ; 1.31]$} \\
\hline Cohabiting partner, no children & 1 & & 1 & \\
\hline Cohabiting partner and children & 0.93 & {$[0.72 ; 1.19]$} & 0.90 & {$[0.70 ; 1.16]$} \\
\hline Other cohabiting adults & 1.13 & {$[0.87 ; 1.46]$} & 1.10 & {$[0.86 ; 1.42]$} \\
\hline \multicolumn{5}{|l|}{ History of intravenous drug use } \\
\hline No & 1 & & 1 & \\
\hline Yes & $2.01 *$ & {$[1.65 ; 2.45]$} & $1.70^{*}$ & {$[1.34 ; 2.17]$} \\
\hline \multicolumn{5}{|l|}{ Health status } \\
\hline \multicolumn{5}{|l|}{ Duration since HIV diagnosis } \\
\hline Less than 3 years & & & 1.01 & {$[0.85 ; 1.20]$} \\
\hline 3 years or more & & & 1 & \\
\hline \multicolumn{5}{|l|}{ Immune status at HIV diagnosis } \\
\hline$<200 \mathrm{CD} 4 / \mathrm{mm}^{3}$ or AIDS & & & $1.58^{*}$ & {$[1.25 ; 1.99]$} \\
\hline $200-349 \mathrm{CD} 4 / \mathrm{mm}^{3}$ & & & 1.11 & {$[0.84 ; 1.47]$} \\
\hline $350-499 \mathrm{CD} 4 / \mathrm{mm}^{3}$ & & & 1.07 & {$[0.83 ; 1.38]$} \\
\hline$\geq 500 \mathrm{CD} 4 / \mathrm{mm}^{3}$ & & & 1 & \\
\hline Missing & & & $1.33^{*}$ & {$[1.03 ; 1.72]$} \\
\hline \multicolumn{5}{|l|}{ ART status and HIV viral load (VL) } \\
\hline On ART, VL $<400$ copies/ml & & & 1 & \\
\hline On ART, VL $\geq 400$ copies $/ \mathrm{ml}$ & & & 1.09 & {$[0.86 ; 1.38]$} \\
\hline Not on ART & & & 1.23 & {$[0.96 ; 1.58]$} \\
\hline Missing & & & $1.86^{*}$ & {$[1.27 ; 2.72]$} \\
\hline \multicolumn{5}{|l|}{ History of Hepatitis C } \\
\hline No & & & 1 & \\
\hline Yes & & & 1.01 & {$[0.80 ; 1.29]$} \\
\hline \multicolumn{5}{|l|}{ Health-Related Quality of Life (HRQL) } \\
\hline Normal & & & 1 & \\
\hline Impaired mental HRQL & & & 1.27 & {$[0.87 ; 1.87]$} \\
\hline Impaired physical HRQL & & & $1.72^{*}$ & {$[1.30 ; 2.28]$} \\
\hline Impaired physical and mental HRQL & & & $2.35^{*}$ & {$[1.82 ; 3.03]$} \\
\hline Missing & & & $2.10^{*}$ & {$[1.65 ; 2.67]$} \\
\hline
\end{tabular}

aPRR: adjusted prevalence rate ratio

Cl: confidence interval $\quad{ }^{*} p<0.05$ 
Table 4. Prevalence rate ratio of unemployment in 2011 versus 2003, adjusted for individual sociodemographic determinants of position on the labor market (Model 1) and additionally for health status characteristics (Model 2)

\begin{tabular}{|c|c|c|c|c|}
\hline & \multicolumn{2}{|c|}{ Model 1} & \multicolumn{2}{|c|}{ Model 2} \\
\hline & aPRR & {$[95 \% \mathrm{Cl}]$} & aPRR & {$[95 \% \mathrm{Cl}]$} \\
\hline \multicolumn{5}{|l|}{ Survey year } \\
\hline 2003 & 1 & & 1 & \\
\hline 2011 & $1.28^{*}$ & {$[1.04 ; 1.57]$} & $1.55^{*}$ & {$[1.24 ; 1.93]$} \\
\hline \multicolumn{5}{|c|}{ Socio-demographic determinants of position on the labor market } \\
\hline \multicolumn{5}{|c|}{ Sex } \\
\hline Men & 1 & & 1 & \\
\hline Women & 0.93 & {$[0.71 ; 1.21]$} & 0.93 & {$[0.72 ; 1.21]$} \\
\hline \multicolumn{5}{|l|}{ Age (years) } \\
\hline $25-39$ & 1.21 & {$[0.96 ; 1.53]$} & 1.15 & {$[0.91 ; 1.44]$} \\
\hline $40-49$ & 1 & & 1 & \\
\hline $50-64$ & $0.58^{*}$ & {$[0.42 ; 0.82]$} & $0.59 *$ & {$[0.42 ; 0.83]$} \\
\hline \multicolumn{5}{|l|}{ Country of citizenship } \\
\hline France & 1 & & 1 & \\
\hline Sub-Saharan Africa & $2.11 *$ & {$[1.62 ; 2.74]$} & $2.16^{*}$ & {$[1.65 ; 2.81]$} \\
\hline Other & $1.52 *$ & {$[1.06 ; 2.17]$} & $1.52^{*}$ & {$[1.06 ; 2.18]$} \\
\hline \multicolumn{5}{|l|}{ Educational level } \\
\hline High & 1 & & 1 & \\
\hline Low & 0.96 & {$[0.74 ; 1.23]$} & 1.00 & {$[0.77 ; 1.28]$} \\
\hline \multicolumn{5}{|l|}{ Household composition } \\
\hline Single, no children & 1.30 & {$[0.92 ; 1.84]$} & 1.27 & {$[0.90 ; 1.79]$} \\
\hline Single with children & $2.11 *$ & {$[1.43 ; 3.13]$} & $2.03^{*}$ & {$[1.38 ; 2.99]$} \\
\hline Cohabiting partner, no children & 1 & & 1 & \\
\hline Cohabiting partner and children & 1.38 & {$[0.94 ; 2.04]$} & 1.38 & {$[0.95 ; 2.02]$} \\
\hline Other cohabiting adults & $1.86^{*}$ & {$[1.28 ; 2.71]$} & $1.69^{*}$ & {$[1.15 ; 2.49]$} \\
\hline \multicolumn{5}{|l|}{ History of intravenous drug use } \\
\hline No & 1 & & 1 & \\
\hline Yes & 1.35 & {$[0.92 ; 1.99]$} & 1.02 & {$[0.64 ; 1.65]$} \\
\hline \multicolumn{5}{|l|}{ Health status } \\
\hline \multicolumn{5}{|l|}{ Duration since HIV diagnosis } \\
\hline Less than 3 years & & & $1.46^{*}$ & {$[1.15 ; 1.85]$} \\
\hline 3 years or more & & & 1 & \\
\hline \multicolumn{5}{|l|}{ Immune status at HIV diagnosis } \\
\hline$<200 \mathrm{CD} 4 / \mathrm{mm}^{3}$ or AIDS & & & 1.00 & {$[0.73 ; 1.38]$} \\
\hline $200-349 \mathrm{CD} 4 / \mathrm{mm}^{3}$ & & & 1.16 & {$[0.83 ; 1.63]$} \\
\hline $350-499 \mathrm{CD} 4 / \mathrm{mm}^{3}$ & & & 0.75 & {$[0.53 ; 1.07]$} \\
\hline$\geq 500 \mathrm{CD} 4 / \mathrm{mm}^{3}$ & & & 1 & \\
\hline Missing & & & 1.19 & {$[0.82 ; 1.72]$} \\
\hline \multicolumn{5}{|l|}{ ART status and HIV viral load (VL) } \\
\hline On ART, VL $<400$ copies $/ \mathrm{ml}$ & & & 1 & \\
\hline On ART, VL $\geq 400$ copies $/ \mathrm{ml}$ & & & $1.52^{*}$ & {$[1.11 ; 2.07]$} \\
\hline Not on ART & & & 1.32 & {$[0.98 ; 1.78]$} \\
\hline Missing & & & 0.73 & {$[0.38 ; 1.40]$} \\
\hline \multicolumn{5}{|l|}{ History of Hepatitis C } \\
\hline No & & & 1 & \\
\hline Yes & & & 1.54 & {$[1.00 ; 2.37]$} \\
\hline \multicolumn{5}{|l|}{ Health-Related Quality of Life (HRQL) } \\
\hline Normal & & & 1 & \\
\hline Impaired mental HRQL & & & 1.15 & {$[0.77 ; 1.72]$} \\
\hline Impaired physical HRQL & & & 0.74 & {$[0.50 ; 1.08]$} \\
\hline Impaired physical and mental HRQL & & & 1.07 & {$[0.76 ; 1.52]$} \\
\hline Missing & & & 0.86 & {$[0.61 ; 1.22]$} \\
\hline
\end{tabular}

aPRR: adjusted prevalence rate ratio

Cl: confidence interval

${ }^{*} p<0.05$ 
Figure 1. Labor market transitions following HIV diagnosis among participants of the VESPA-2003 and VESPA-2011 surveys diagnosed HIV-infected within the $\mathbf{3 6}$ months preceding interview

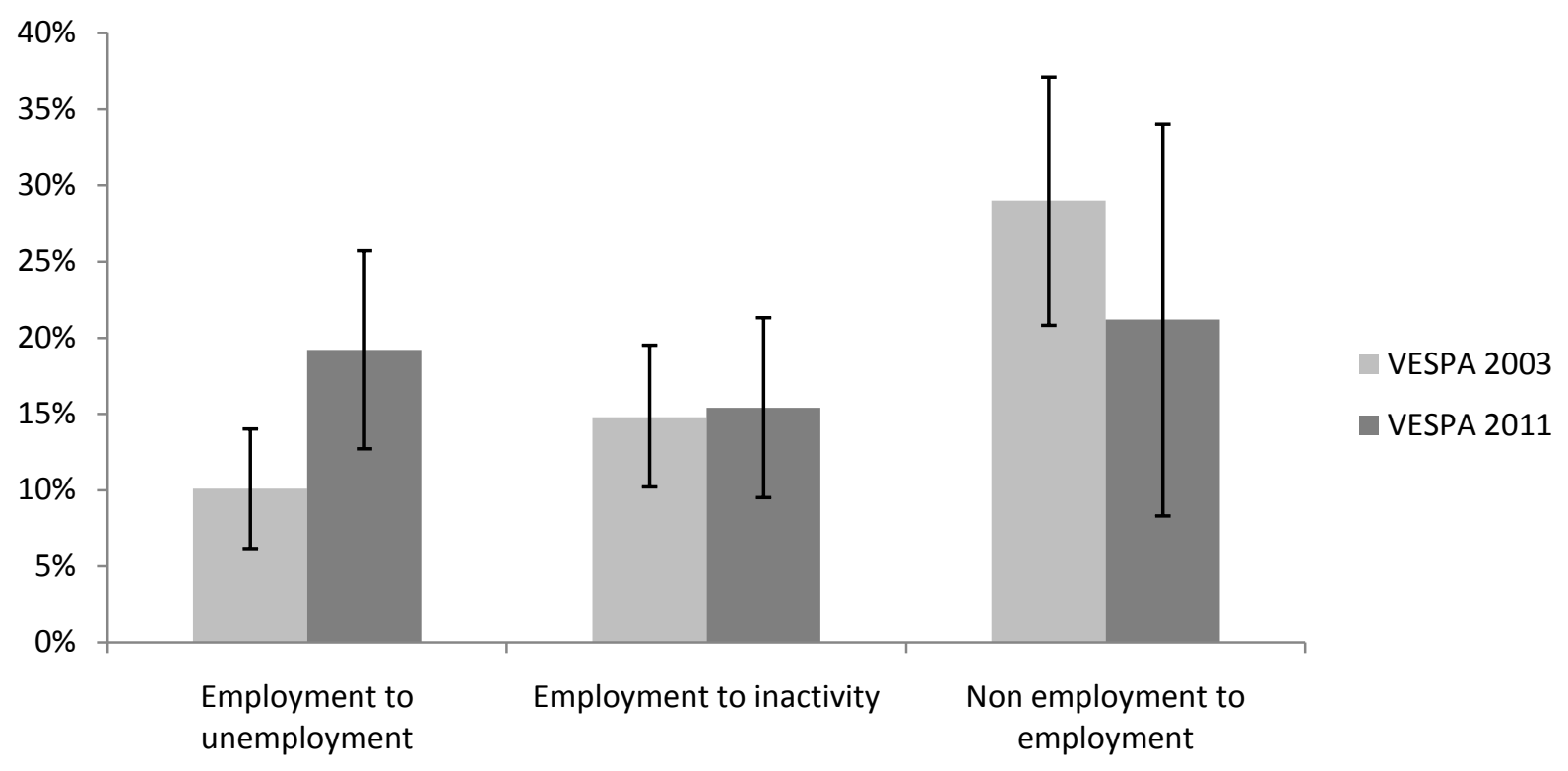




\section{Supplementary material}

Table S1. Socio-demographic determinants of position on the labor market and health status characteristics of participants of the VESPA-2003 and VESPA-2011 surveys diagnosed HIV-infected within the 36 months preceding interview

\begin{tabular}{|c|c|c|c|}
\hline & $\begin{array}{l}\text { VESPA-2003 }^{a} \\
(\mathrm{~N}=427)\end{array}$ & $\begin{array}{l}\text { VESPA-2011 }{ }^{\mathrm{a}} \\
(\mathrm{N}=366)\end{array}$ & $P$-value ${ }^{b}$ \\
\hline \multicolumn{4}{|c|}{ Socio-demographic determinants of position on the labor market } \\
\hline \multicolumn{4}{|c|}{ Sex } \\
\hline Men & 62.8 & 63.9 & 0.79 \\
\hline Women & 37.2 & 36.1 & \\
\hline \multicolumn{4}{|l|}{ Age (years) } \\
\hline $25-39$ & 56.8 & 54.6 & 0.84 \\
\hline $40-49$ & 26.2 & 28.0 & \\
\hline $50-64$ & 17.0 & 17.4 & \\
\hline \multicolumn{4}{|l|}{ Country of citizenship } \\
\hline France & 56.6 & 58.0 & 0.14 \\
\hline Sub-Saharan Africa & 34.1 & 37.2 & \\
\hline Other & 9.3 & 4.8 & \\
\hline \multicolumn{4}{|l|}{ Educational level } \\
\hline High & 29.0 & 33.5 & 0.31 \\
\hline Low & 71.0 & 66.5 & \\
\hline \multicolumn{4}{|l|}{ Household composition } \\
\hline Single, no children & 37.5 & 35.4 & 0.61 \\
\hline Single with children & 10.2 & 14.6 & \\
\hline Cohabiting partner, no children & 22.5 & 21.8 & \\
\hline Cohabiting partner and children & 14.3 & 12.3 & \\
\hline Other cohabiting adults & 15.5 & 15.9 & \\
\hline \multicolumn{4}{|l|}{ History of intravenous drug use } \\
\hline No & 97.7 & 98.2 & 0.66 \\
\hline Yes & 2.3 & 1.8 & \\
\hline \multicolumn{4}{|l|}{ Health status } \\
\hline \multicolumn{4}{|l|}{ Immune status at HIV diagnosis } \\
\hline$<200 \mathrm{CD} 4 / \mathrm{mm}^{3}$ or AIDS & 37.6 & 29.1 & 0.03 \\
\hline $200-349 \mathrm{CD} 4 / \mathrm{mm}^{3}$ & 20.7 & 19.2 & \\
\hline $350-499 \mathrm{CD} 4 / \mathrm{mm}^{3}$ & 13.7 & 24.6 & \\
\hline$\geq 500 \mathrm{CD} 4 / \mathrm{mm}^{3}$ & 24.1 & 23.6 & \\
\hline Missing & 3.9 & 3.5 & \\
\hline \multicolumn{4}{|l|}{ ART status and HIV viral load (VL) } \\
\hline On ART, VL <400 copies/ml & 57.1 & 69.7 & 0.01 \\
\hline On ART, VL $\geq 400$ copies $/ \mathrm{ml}$ & 10.2 & 4.4 & \\
\hline Not on ART & 31.1 & 23.0 & \\
\hline Missing & 1.6 & 2.9 & \\
\hline \multicolumn{4}{|l|}{ History of Hepatitis C } \\
\hline No & 94.0 & 97.0 & 0.05 \\
\hline Yes & 6.0 & 3.0 & \\
\hline \multicolumn{4}{|l|}{ Health-Related Quality of Life (HRQL) } \\
\hline Normal & 21.4 & 19.5 & 0.001 \\
\hline Impaired mental HRQL & 12.6 & 8.0 & \\
\hline Impaired physical HRQL & 13.3 & 20.9 & \\
\hline Impaired physical and mental HRQL & 14.5 & 24.6 & \\
\hline Missing & 38.2 & 27.0 & \\
\hline
\end{tabular}

${ }^{\mathrm{a}}$ Weighted percentages $\quad{ }^{\mathrm{b}}$ Chi-square test 


\section{Appendix}

\section{Members of the ANRS-VESPA2 Study Group}

France Lert (INSERM UMR-S 1018, France.Lert@inserm.fr) and Bruno Spire (INSERM UMR-S 912/ORS PACA), scientific coordinators; Patrizia Carrieri (INSERM UMR-S 912/ORS PACA), Rosemary Dray-Spira (INSERM UMR-S 1136), Christine Hamelin (University Versailles Saint-Quentin-en-Yvelines), Nicolas Lorente (INSERM UMR-S 912/ORS PACA), Marie Pré au (INSERM UMR-S 912/ORS PACA), Marie Suzan-Monti (INSERM UMR-S 912/ORS PACA); with the collaboration of Marion Mora (INSERM UMR-S 912/ORS PACA).

\section{Participating hospitals and investigators}

Aix-en-Provence, CH Pays d'Aix (T. Allègre, P. Mours, J.M. Riou, M. Sordage); Angers, CHU Hôtel-Dieu (J.M. Chennebault, P. Fialaire, V. Rabier) ; Annemasse, CH Alpes-Léman (M. Froidure, D. Huguet, D. Leduc) ; Avignon, Hôpital Henri Duffaut (G.P ichancourt, A. Wajsbrot) ; Besançon, Hôpital Saint-Jacques (C. Bourdeaux, A. Foltzer, B. Hoen, L. Hustache-Mathieu) ; Bobigny, Hôpital Avicenne (S. Abgrall, R. Barruet, O. Bouchaud, A. Chabrol, S. Mattioni, F. Mechai) ; Bondy, Hôpital Jean Verdier (V. Jeantils) ; Bordeaux, Hôpital Saint-André (N. Bernard, F. Bonnet, M. Hessamfar, D. Lacoste, D. Malvy, P. Mercié, P. Morlat, F. Paccalin, M.C. Pertusa, T. Pistone, M.C. Receveur, M.A. Vandenhende) ; Boulogne-Billancourt, Hôpital Ambroise Paré (C. Dupont, A. Freire Maresca, J. Leporrier, E. Rouveix) ; Caen, Hôpital Clémenceau (S. Dargere, A. de la Blanchardière, A. Martin, V. Noyon, R. Verdon) ; CH de Chambéry (O. Rogeaux) ; Clermont-Ferrand, CHU Gabriel Montpied (J. Beytout, F. Gourdon, H. Laurichesse) ; Colombes, Hôpital Louis-Mourier (F. Meier, E. Mortier, A.M. Simonpoli) ; Creil, CH Laennec (F. Cordier) ; Créteil, CHIC (I. Delacroix, V. Garrait, B. Elharrar), Hôpital Henri Mondor (S. Dominguez, A.S. Lascaux, J.D. Lelièvre, Y. Levy, G. Melica) ; Dijon, Hôpital du Bocage (M. Buisson, L. Piroth, A. Waldner) ; Eaubonne, Hôpital Simone Veil (N. Gruat, A. Leprêtre) ; Garches, Hôpital Raymond-Poincaré (P. de Truchis, D. Le Du, J.Cl. Melchior) ; $\mathrm{CH}$ de Gonesse (R. Sehouane, D. Troisvallets) ; CHU de Grenoble (M. Blanc, I. Boccon-Gibod, A. Bosseray, J.P. Brion, F. Durand, P. Leclercq, F. Marion, P. Pavese); La Rochelle, Hôpital Saint- Louis (E. BrottierMancini, L. Faba, M. Roncato-Saberan) ; La Roche-sur-Yon, CHD Les Oudairies (O. Bollengier-Stragier, J.L. Esnault, S. Leautez-Nainville, P.P erré) ; CH de Lagny Marne-la-Vallée (E. Froguel, M. Nguessan, P. Simon) ; Le Chesnay, CH de Versailles (P. Colardelle, J. Doll, C. Godin-Collet, S. Roussin-Bretagne) ; Le Kremlin-Bicêtre, Hôpital de Bicêtre (J.F. Delfraissy, M. Duracinsky, C. Goujard, D. Peretti, Y. Quertainmont) ; $\mathrm{CH}$ du Mans (J. Marionneau) ; Lens, CH Dr. Schaffner (E. Aissi, N. Van Grunderbeeck) ; Limoges, CHU Dupuytren (E. Denes, S. Ducroix-Roubertou, C. Genet, P. Weinbreck) ; Lyon, Hôpital de la Croix-Rousse (C. Augustin-Normand, A. Boibieux, L. Cotte, T. Ferry, J. Koffi, P. Miailhes, T. Perpoint, D. Peyramond, I. Schlienger); Hôpital Édouard-Herriot (J.M. Brunel, E. Carbonnel, P. Chiarello, J.M. Livrozet, D. Makhloufi) ; Marseille, Hôpital de la Conception (C. Dhiver, H. Husson, A. Madrid, I. Ravaux, M.L. de Severac, M. Thierry Mieg, C. Tomei), Hôpital Nord (S. Hakoun, J. Moreau, S. Mokhtari, M.J. Soavi), Hôpital Sainte Marguerite (O. Faucher, A. Ménard, M. Orticoni, I. Poizot-Martin, M.J. Soavi) ; Montpellier, Hôpital Gui de Chauliac (N. Atoui, V. Baillat, V. Faucherre, C. Favier, J.M. Jacquet, V. Le Moing, A. Makinson, R. Mansouri, C. Merle) ; Montivilliers, Hôpital Jacques Monod (N. Elforzli) ; Nantes, Hôtel-Dieu (C. Allavena, O. Aubry, M. Besnier, E. Billaud, B. Bonnet, S. Bouchez, D. Boutoille, C. Brunet, N. Feuillebois, M. Lefebvre, P. Morineau-Le Houssine, O. Mounoury, P. Point, F. Raffi, V. Reliquet, J.P. Talarmin) ; Nice, Hôpital I'Archet (C. Ceppi, E. Cua, P. Dellamonica, F. De Salvador-Guillouet, J. Durant, S. Ferrando, V. Mondain-Miton, I. Perbost, S. Pillet, B. Prouvost-Keller, C. Pradier, P. Pugliese, V. Rahelinirina, P.M. Roger, E. Rosenthal, F. Sanderson) ; Orléans, Hôpital de La Source (L. Hocqueloux, M. Niang, T. Prazuck), Hôpital Porte Madeleine (P. Arsac, M.F. Barrault-Anstett) ; Paris , Hôpital Bichat - Claude-Bernard (M. Ahouanto, E. Bouvet, G. Castanedo, C. Charlois-Ou, A. Dia Kotuba, Z. Eid-Antoun, C. Jestin, K. Jidar, V. Joly, M.A. Khuong-Josses, N. Landgraf, R. Landman, S. Lariven, A. Leprêtre, F. L'hériteau, M. Machado, S. Matheron, F. Michard, G. Morau, G. Pahlavan, B.C. Phung, M.H. Prévot, C. Rioux, P. Yéni), Hôpital Cochin-Tarnier (F. Bani-Sadr, A. Calboreanu, 
E. Chakvetadze, D. Salmon, B. Silbermann), Hôpital européen Georges-Pompidou (D. Batisse, M. Beumont, M. Buisson, P. Castiel, J. Derouineau, M. Eliaszewicz, G. Gonzalez, D. Jayle, M. Karmochkine, P. Kousignian, J. Pavie, I. Pierre, L. Weiss), Hôpital Lariboisière (E. Badsi, M. Bendenoun, J. Cervoni, M. Diemer, A. Durel, A. Rami, P. Sellier), Hôpital Pitié-Salpêtrière (H. Ait-Mohand, N. Amirat, M. Bonmarchand, F. Bourdillon, G. Breton, F. Caby, J.P. Grivois, C. Katlama, M. Kirstetter, L. Paris, F. Pichon, L. Roudière, L. Schneider, M.C. Samba, S. Seang, A. Simon, H. Stitou, R. Tubiana, M.A. Valantin), Hôpital Saint-Antoine (D. Bollens, J. Bottero, E. Bui, P. Campa, L. Fonquernie, S. Fournier, P.M. Girard, A. Goetschel, H.F. Guyon, K. Lacombe, F. Lallemand, B. Lefebvre, J.L. Maynard, M.C. Meyohas, Z. Ouazene, J. Pacanowski, O. Picard, G. Raguin, P. Roussard, M. Tourneur, J. Tredup, N. Valin) ; Hôpital Saint-Louis (S. Balkan, F. Clavel, N. Colin de Verdière, N. De Castro, V. de Lastours, S. Ferret, S. Gallien, V. Garrait, L. Gérard, J. Goguel, M. Lafaurie, C. LascouxCombe, J.M. Molina, E. Oksenhendler, J. Pavie, C. Pintado, D. Ponscarme, W. Rozenbaum, A. Scemla), Hôpital Tenon (P. Bonnard, L. Lassel, M.G. Lebrette, T. Lyavanc, P. Mariot, R. Missonnier, M. Ohayon, G. Pialoux, M.P.Treilhou, J.P. Vincensini) ; Hôtel-Dieu (J. Gilquin, B. Hadacek, L. Nait-Ighil, T.H. Nguyen, C. Pintado, A. Sobel, J.P. Viard, O.Zak Dit Zbar) ; Perpignan, Hôpital Saint-Jean (H. Aumaître, A. Eden, M. Ferreyra, F. Lopez, M. Medus, S. Neuville, M. Saada) ; Pontoise, CH René Dubos (L. Blum) ; Quimper, Hôpital Laennec (P. Perfezou) ; Rennes, Hôpital de Pontchaillou (C. Arvieux, J.M. Chapplain, M. Revest, F. Souala, P. Tattevin) ; Rouen, Hôpital Charles-Nicolle (S. Bord, F. Borsa-Lebas, F. Caron, C. Chapuzet, Y. Debab, I. Gueit, M. Etienne, C. Fartoukh, K. Feltgen, C. Joly, S. Robaday-Voisin, P. Suel) ; Saint-Denis, CH Delafontaine (M.A. Khuong, J. Krausse, M. Poupard, G. Tran Van) ; Saint-Étienne, CHU Nord (C. Cazorla, F. Daoud, P. Fascia, A. Frésard, C. Guglielminotti, F. Lucht) ; Strasbourg, Nouvel hôpital civil (C. BernardHenry, C. Cheneau, J.M. Lang, E. de Mautort, M. P artisani, M. Priester, D. Rey) ; Suresnes, Hôpital Foch (C. Majerholc, D.Zucman) ; Toulon, CHI Chalucet (A. Assi, A. Lafeuillade), Hôpital Sainte-Anne (J.P. de Jaureguiberry, O. Gisserot) ; Toulouse, Hôpital de La Grave (C. Aquilina, F. Prevoteau du Clary), Hôpital Purpan (M. Alvarez, M. Chauveau, L. Cuzin, P. Delobel, D. Garipuy, E. Labau, B. Marchou, P. Massip, M. Mularczyk, M. Obadia) ; Tourcoing, CH Gustave Dron (F. Ajana, C. Allienne, V. Baclet, X. de la Tribonnière, T. Huleux, H. Melliez, A. Meybeck, B. Riff, M. Valette, N. Viget) ; Tours, CHRU Bretonneau (F. Bastides, L. Bernard, G. Gras, P. Guadagnin) ; Vandoeuvre-lès-Nancy, CHU Brabois (T. May, C. Rabaud) ; Vannes, CH Bretagne Atlantique (A. Dos Santos, Y. P oinsignon); Villejuif, Hôpital Paul-Brousse, (O. Derradji, L. Escaut, E. Teicher, D. Vittecoq); CHI de Villeneuve-Saint-Georges, (J. Bantsima, P. Caraux-Paz, O. Patey). 